\title{
The Romanow gaps: some closing, others still open
}

W

ith considerable relief, Canada's First Ministers announced in the small hours of Sept. 16 that they had gotten the message that taxpayers were fed up with long waiting lists and wanted more (of their own) money spent on health care. The federal component of public spending on health care will increase by $\$ 18$ billion over 6 years, with an "escalator" formula bringing this new money to $\$ 41.2$ billion by 2014 . This is enough - more than enough - to rectify the shortfall in federal contributions identified by Mr. Romanow's commission on health care - the so-called "Romanow gap." The cash boost is welcome: most experts agree that the Canadian health care system is underfunded. But will it be enough to bring about the "transformative change" needed to meet Romanow's recommendations - to close the other Romanow gaps?

Although the amount seems large, it works out to only a modest annual increase - roughly $3.5 \%$ of total public expenditures on health care. Yet health care expenditures are increasing at a rate of $6 \%-8 \%$ per year, a rate of increase that is widely expected to continue, if not accelerate, as a tsunami of new technology surges into offices and hospitals. Even if the new money can be directed to reducing some waiting lists, patching home care and paying for catastrophic drug costs, it is unlikely that the average physician or patient will notice much difference.

In preparing his recommendations Romanow carefully examined the evidence that the public health care system was sick, assessed its resources, made a diagnosis and prescribed a program for rehabilitation. Money was part of it. But he also diagnosed system failures that cannnot be fixed with an injection of cash. During September's health care conference $\infty$ hardly any of these failures were discussed. The First Ministers are well versed in the ailments of public health care and in how difficult they will be to remedy. But, as Alberta premier Ralph Klein bluntly put it, "The whole conference was about money, nothing else." There had to be an outcome in this reality-TV intergovernmental sparring (even if it was determined off-camera), and cash was the easiest. The Prime Minister attempted to insert some controls over the use of federal transfers, including, importantly, national reporting of some health system performance measures such as waiting times. But the agreement neglected the rest of the reforms proposed by Mr. Romanow.

For Mr. Romanow, reform requires fundamental changes to the way health care is delivered. For the other Romanow gaps include that between the public's expectations and real sustainability; between the complexity of modern medical care and the informational infrastructure needed to reduce inefficiency; and between existing scopes of practice and the integrated teamwork now required. Regarding the latter, hardly a word was spoken of primary care reform. Reform is such a polite word. But what it means, among other things, is redefining the roles and responsibilities of health care providers, particularly nurses and physicians.

Reform, the sleeping elephant in the living room that we continue to step around quietly. Implementing the hard parts of the Romanow reforms falls to the provincial governments, the professions and existing institutions such as hospitals. If provincial health care systems are to survive they will have to change the way professionals work together. Accomplishing these and other changes (such as the role of the private sector) will require public involvement and changes to public expectations. Health care budgets cannot keep growing at current above-inflation rates. Canada needs open, informed public discussions, not of the latest anecdotes of desperate patients waiting for cataract or cancer surgery, but of the data on how the health care system is functioning. And Canadians will need to debate their other collective responsibilities to future generations (who will bear the burden of the increasing costs) with respect to education, housing, child care and environmental protection; these are, no less than medical care, necessary to the nations' health. - CMAF

\section{Reference}

1. Romanow RJ. Building on values: the future of bealth care in Canada. Saskatoon: Commission on the Future of Health Care in Canada. 2002. Available: www.healthcarecommission.ca (accessed 2004 Sept 20). 